\title{
Index
}

Note: Page numbers in italics indicate figures.

955,00o exhibition 78, 85n121, 106, 133

Aboriginal Canadians see First Nations Aboriginal subjectivity, stereotype of 21048

Aboriginal title 61-2, 155, 223

absorption 18n3, 36, 38, 47n49, 177

abstract painting 2, 95

abstraction 2, 93

Acconci, Vito 173, 19on26

Adorno, Theodor 44n12, 91

advertising 132, 142, 150, 171

Africa Explores: 2oth-Century African

Art exhibition 232

a-historicism 89-91, 156

Anderson, Benedict 54, 82-3n62, 86, 89

Anglophone Canadian experience 50-1 anti-capital stance 101, 105-6, 123, 202

anti-immigrant sentiment 55, 57, 59-60, $62,71,81 n 38$

anti-modernist rhetoric $57-8$

anti-theatricality 4, 18n 3

Antonioni, Michelangelo 129-30, 187

the 'a-photographic' 167

Arden, Roy 2, 15, 163, 238, 240

art

as analytic proposition 93

artworks as fields of conflict $171-7$

autonomy within bourgeois society 91

cleaved from art market 164 dematerialization of 164

'double character of' 91

federal support for 97

male dominance in arts 172

modernist discourse about 223

ontology of 164

spirituality and 52-3

as transfer narrative 87

Art and Language group 171, $190 n 17$

Art Gallery of Greater Victoria 24-5, 29, 168,177

art history

art-historical canon 1, 9, 16-17, 150, $172,195,197,201,236,244$

art-historical discourse 91-3, 176, 223, 235-7

feminist $26,192-3$

lack of $89-90$

sexism of 201

as territory in play $13-17$

as transfer narrative 87

art market 1, 2-3, 16-17, 97, 164, 172, 203, 239-41

'art of high interiority' 184-5, 186

artists 156

artist as shaman 11,12

biographies as location-based branding 240-1

of colour 231-3, 237

professional practice of 186

see also male artists; women artists

Artropolis 229 
artscanada 5-6, 11-12, 77, 78, 102-3, 105, 123,133

assimilationist policies 65

Atkinson, Terry 235

Atwood, Margaret 199

authorship

feminist critique of 40

gender and 151-2

rejection of traditional 167

avant-garde(s) 3-4, 7-8, 88, 91-3, 150, $171,186,188,202,220,228,238$

in 1960 s Vancouver 10

American 3

cinema 136,187

critical disinterest in framing Penner

Bancroft within history of 213

critiques of 196-7

discourse(s) of 3, 6, 7-11, 13-14, 17, $196-7,216,233,237$

feminism and 13, 192-3, 202, 244

formation of 9-10

gendered 8-9, 12, 16, 234

identity formation and 10

international $16-17$

new territories emerging out of history of 7-11

others and 12

Penner Bancroft, Marian and 215-16

photo-conceptualism and 244

political concerns of 240

politics 3-4, 233

poststructuralist analyses of 8-9

race and 12

as 'reaction formation' 9

as social process with global implications 4

as spectacle 233

in Vancouver, British Columbia 3-5,

$$
\text { 7-13, 148-9, 193-4 }
$$

Wall and 30, 36, 40

Babyland 101, 102, 105

Bachelard, Gaston 218

'back to the land' lifestyle movement

$$
11-12,13,16,96
$$

Baldwin Street Gallery 204

Balkind, Alvin 101, 198, 217, 219-20, 229

Ball, Hugo 8

Bancroft, Marian Penner see Penner Bancroft, Marian

Barbeau, Marius 63, 66

Barker, Adam 61, 82n60

Barling, Marion 198-9, 202

Barthes, Roland 172, 181

Baxter, Iain 10, 78, 97-8, 114-23, 151-3, 156, 157-8n15, 161n91, 193

Baxter, Ingrid (formerly Elaine) 10, 78, 97, 114-23, 150-3, 157-8n15, 157n1, 161n88, 193

Beck, Claudia 204

beholding 36-7

Bell, Dennis 151, 152

Bellmer, Hans 169

Benjamin, Walter 27-8, 30

Adorno and 44n12

'The Work of Art in the Age of Mechanical Reproduction' 28, 43-4n10, 44n11, 44n12

Berlin Dada 91-3

Besant, Annie 71

Beuys, Joseph 218

Beveridge, Karl 171, 190n17

Beyond History exhibition 232

Bischoff, Alexandra 224n15

Blavatsky, Helena Petrovna 52-3, 71

Blomley, Nicholas 156, 238-9

Boddy, Trevor 241, 247n 58

bodies 164, 165

see also female bodies

bourgeois society 9, 11, 28, 164, 169, 220

Braun, Bruce 12, 76

Brauntuch, Troy 43n1

Breton, André 45n21, 134, 193

British Columbia 42

counterculture in $96-7$

Expressionist landscape painting in 24

Nisga'a lawsuit against 155

as settler state $61-2,96$ 
tourism in 66

see also Vancouver, British Columbia

Brown, Eric 63-4, 67

Brown, Rosemary 194

Brutopia 101

Buchloh, Benjamin 27, 28, 43-4n1o,

$$
47-8 \mathrm{n} 56
$$

Bucke, R.M. 52, 8on22

Buckley, John 105

Burden, Chris 30, 173

Buren, Daniel 128-9

Burlingham, Cynthia 79n3

Burn, Ian 128

Burrows, Tom 5, 89, 104-5, 106

Four Artists exhibition 123

Mudflat Sculptures 100

Untitled, Documentation of Mud Flats Sculpture 99, 165

Butler, Connie 193

Butler, Margot 245n17

Butor, Michel 131

Byrne, Kitty 190022

the camera $133-6,183-4$

Cameron, Eric 18o, 181

Canada, centenary of its Confederation 77

Canada Council 97, 101, 117

'Canadian Art' 63-4, 65-6

'Canadian' culture, definition of 97

Canadian identity $13,15,50-1,53-6$, $75-6,81-2$ n 49,92

Canadian landscape 42, 49-51, 53-6o, $59-62,71$

Canadian Multicultural Act 231-2

Canadian Museum of Civilization 232

Canadian National Railway 66

Canadian nationalism 49-54, 67, 109-10

Canadian Pacific Railway (CPR) 154, 238

Canadian 'race' 54-6

Canadian Shield 13

Canadian wilderness 71-2, 81n31

capitalism 7, 15, 17, 28, 33, 44n12, 94, 132, $150,156,213,233,241-2,244$

Carmichael, Franklin 55
Carr, Emily 6-7, 11-13, 15, 42, 49-85, 90, 94

as apolitical Expressionist painter 95 assessments of her work 78, 87, 94-5

D'Sonoqua and 72, 74, 244

established as a national culture treasure $77-8$

Exhibition of Canadian West Coast Art: Native and Modern 63-7, $69,72,74$

female embodied experience and 75-6

initial exposure to Group of Seven painters $69-70$

as intuitive $76,77,78,102-3$

journals of 74,77

Native art and $76-7$

nature and $74-5$

O'Keeffe and 84-5n107

as 'organic artist' $74-6,95,111 n_{34}, 128$

as 'originary figure' 67

portrayed as anti-intellectual $76-7$

as quintessential West Coast artist 79

on rejection of her work $69,84 \mathrm{n} 82$

as role model for 'back-to-the-land' artists 103

as romantic, eccentric outsider 77

settler colonialism and 68-9, 71-2, $75-6,84 \mathrm{n} 83$

sexuality and $74-5$

slighted by men 74

as symbolic matriarch for Vancouver artists 95, 237

symposium on 237

see also Carr, Emily, works

Carr, Emily, works

Big Raven 78

Cedar Cannibal House in Ucluelet, B.C. 103

D'Sonoqua of the Cat Village 103

Guyasdoms D'Sonoqua 73

Indian Woman, Possibly Susan Dan 103

Klee Wyck 68-9, 72

The Raven 70

Reforestation 103 
Tanoo, Queen Charlotte Islands 68, 70 Tree (Spiralling Upward) 75

Trees in the Sky 77 Wood Interior 75

Carr-Harris, Ian 223

Casati, Louisa 185, 186

Caws, Mary Ann 135

Chevrier, Jean-François 39, 46n45, 190 n17

Chicago, Judy 151, 161 7n 8

The Birth Project 231

The Dinner Party 198

Chisholm, Shirley 194

Chrismas, Douglas 98, 106, 108

Cibachrome photography 115, 163

cinema 3, 27-8, 44n12, 135-6, 195-6

cinematographic photography 192, 210

cities 130, 134

branding of 241-2

city grid 130, 131, 133-4

imagery of 150

representation of 135

as sign systems 135

see also urban development; urban

landscapes; 'urban semiotic'

Clark, T.J. 9, 47-8n56, 176-7

The Painters of Modern Life: Manet and His Followers 164

class 37,58

see also bourgeois society

Clayoquot Sound 222-3

Clement, Loretta 245n17

Clemente, Francesco 3

Coal Harbour 154

The Collage Show 126, 143

collages 170-1

collectives 105, 200

see also specific collectives

colonialism 12-13, 15, 17, 41-2, 51, 68, 87, 222

gender and $82 n 58$

indigenous sovereignty and $60-7$

myth of terra nullius 90

nature and $82 \mathrm{n} 58$

rationalization of territorial conquest and 71 commercial visual culture 114, 166

commodity culture, critique of 217

Commonwealth modernism 49-85, 123

Commonwealth romanticism 88

conceptual art 2, 39-40, 44-5n17, 78, 79, $128,131,177,217$

history of 235,240

located everywhere and nowhere 240

pictorialism and 169

representation and 169

see also photo-conceptualism

conceptual artists

anti-market and dematerialized interests and 101

language and 123, 125, 126, 128

see also photo-conceptual artists

concrete poetry $16,123,125$

Condé Carol 171, $190 n 17$

consciousness 38, 93, 171, 202

consciousness-raising 195, 199, 222

false 91

modern 35-6

photography's role in fostering 32-3

technology and 35-6

Constructivism 28

consumerism 4, 143

contemporary art, as propaganda for neoliberal capitalism 241-2

context, notion of 91-5

'Cosmic Consciousness' 52, 8on22

counterculture $13,96-7$

'counter-tradition' 87, 150-1, 163-91, 164, $189,192,238,242$

Courbet, Gustave 8

coureur des bois 86

Courtauld Art Institute 171

Craig, Kate 101

Crary, Jonathan 47n 48

Crimp, Douglas 23, 27, 43n1, 43-4n1o, $45 \mathrm{n} 18,240$

Cronon, William 52

Crosby, Marcia 21n 48

Crow, Thomas 47-8n56, 172 
Cucchi, Enzo 3

'Culture Industry' 233

Curtis, Edward S. The North American Indian 221-2

Da Vinci, Leonardo, Madonna and Child with St Anne 1

Dada $8,16,28,30,57,91-3,128,130$, $168-9,192$

Daly, Mary 199

Danzker, Jo-Anne Birnie 89-91

David, Jacques-Louis 29

Davidson, Ian 108

De Baere, Bart 2, 5

De Beauvoir, Simone 194

De Courcy, Michael 98

De Duve, Thierry 4, 34

Debord, Guy 131-2

'defeatured landscape' 4-7, 12, 16, 43, 110, $163,192,211,237,240,244$

beliefs in 148-9

building discourse of 123-34

cameras and 133-4

Carr and 78-9

cars and 133-4

in The Destroyed Room 23-4

first use of term 123

identity formation and 10

indigenous people in 148-9

limitations of 202

male identity and 149

nature in $148-9$

NETCO as precursor of 150

photography of $147-8$

power relations and 150

regional context and 156

sexuality in 148-9

theory and practice of 114-62

the unconscious in 148-9

Wheeler's proposal of as radical discourse 217

women in 148-9

Delacroix, Eugène 11, 30, 37

Delvaux, Paul 169

dérive 132, 133, 136, 137, 147, 167, 244
Detheridge, Allan 217

détournement 130, 132, 133

Diamond, Sara 200, 228, 245n17

'The Boys Club' 234-5, 246n32

Dikeakos, Christos 2, 5, 16, 106, 110, 114, 126, 130, 200, 203

avant-gardes and 193-4

B.C. Almanac(h) C.-B. 165-6

on collages $170-1$

'counter-tradition' and 193-4, 238

Instant Photo Information 165-6, 165, $167,210-11$

Penner Bancroft and 210-11

solo exhibition at Vancouver Art Gallery 246n32

Street Scans Car Rides 166-7, 166

Vicinity of Cambie Bridge, Vancouver 238

Dikeakos, Sophie 200

discourse 237-42

communities 14-15

critical discourse analysis $13-14$

discursive framing $1-2,14-16,240-1$

discursive marking 156

formation 5, 13-14, 17, 175

landscape and 171, 239-40

territory and $237-42$

see also specific discourses

Dixon, Joy 71

documentary practices $7,114,197,199$, 203-4

domestication $87,88,216$

domesticity 134, 138, 141, 150, 151

Douglas, Stan 2, 15, 38, 47n53, 136, 228-30

D'Sonoqua 72, 74, 103, 244

Dubreuil-Blodin, Nicole 40-1, 47-8n56

Duchamp, Marcel 45n21, 57, 167-9, 193

Bottle Rack 93

The Bride Stripped Bare by her Bachelors, Even (The Large

Glass) 169

'The Creative Act' 164

Étant donnés 16, 30, 141, 167-9

Fountain 243 
Manual of Instructions for the Assembly of Étant donnés 167-70, 168, 189n11

Nude Descending a Staircase 243 readymades $16,93,117,126,163,164$

earthworks 16, 109, 133

Edmonton Art Gallery 152, 222

Egbert, Donald 7-8

Eisenstein, Sergei 27, 181

elimination, logic of 39-43

Ellison, Ralph, Invisible Man 37, 46n40

Éluard, Paul 134

Emerson, Ralph Waldo 52

Emery, Tony 98, 229

Emily Carr: A Centennial Exhibition Celebrating the One Hundredth Anniversary of Her Birth 77-9

Emily Carr College of Art + Design 2 'Emily Carr Symposium' 246-7n45 Engels, Friedrich 198-9 environmentalism 88-9, 154, 222 Epstein, Jean 180

Erickson, Arthur 114

eroticism $32-3,35,42-3,134-5,137-8$, $141-2,148,150,175,196$

see also sexuality

essentialism, critiques of 196

Eternal network 101

ethnic mixing 51, 58

exclusion 8-9, 17, 234, 242

Exhibition of Canadian West Coast Art:

Native and Modern 66-7, 69,

72,74

Exhibition of Contemporary

Scandinavian Art 57, 81-2n49

exhibitions 17

all-women 201

blockbuster exhibitions in 1970s 28

feminist 201-2

multicultural 231-3

women-only 197

see also specific exhibitions

exogenous others $61-3,86,156-7,215$, 216
Expo '86 2, 17, 228, 238, 241, 244

Expressionism 6, 13, 16, 24, 42, 79, 92-3, 94, 95, 109, 131

eyes see vision

Falk, Gathie 217

False Creek 154, 228

Fauvism 68

featured landscape, conflicts in $153-7$

female bodies $16,75-6,120-1,123$, $134-53,170,175,192$

control of 169

critique of objectification of during 1970s 169

feminist performance art and 195

naked, found in forests and natural landscapes 169

representation of $195,242-4$

see also women, representation of

'female' point of view 203-4

female power 75

'Female Representation' panel discussion 231

female sexuality, forests and 75-6

the feminine 193, 202, 215

femininity $74-5,174-5,196,214-15$

feminism $152-3,161 \mathrm{n} 87,161 \mathrm{n} 88,170-1$, $178,184,189,192,218,222$

avant-gardes and 202

feminist action vs. feminist theory 234-5

photo-conceptualists and 202

use of the term 201-2

see also women's movement

feminist

art history 9, 26, 192-3, 230-1

art practices 9, 16, 171, 186, 192-227, 230-1

avant-garde $13,16-17,192-3,244$

collectives 200

discourse 10, 40, 187-9

field of conflict 176

filmmaking 197, 198, 200, 201-2

geography 150

performance art 195, 224n9 
screen theory 9, 11

theory 16, 40, 186-7, 192-227, 234-5 see also feminist screen theory video 197

Feminist Avant-Garde of the 1970s 193, 223-4n1

Festival '82: A Celebration of Women in the Arts 231

Festival of the Contemporary Arts 98, 114

fetish, theory of the $175,195-6$

fields of conflict 171-7

figuration 4, 189

Filliou, Robert 101

film see cinema

filmmaking, feminist 197, 198, 200

film theory $47 \mathrm{n} 54$

see also feminist screen theory

Fine Arts Gallery, University of British

Columbia 5-6, 117, 119-20, 123, 125,126

First Nations 12, 42, 51, 61, 66-9, 72, 76, $81 n 38,87,154-6$

appropriations of 7

assimilation of 65

Carr and 103

cultural traditions of $88-9$

images of 7

land rights of $66-7,222$

at Mudflats 100-1

settler appropriation of Native land and $222-3$

see also specific nations

First Nations artists 63, 64, 231-3, 237

flâneur 134, 135, 141, 147, 156

Florida, Richard 19n15

forest imagery $7,70-1,75-6,169$

formalism 4, 128, 172, 240

Foster, Hal 48n6o

Foucault, Michel 14, 131, 172, 212

found photographs 165,167

Four Artists exhibition 5-6, 123, 126,

$$
\text { 127-30, 143, } 217
$$

Four Places exhibition 217, 218

Frankfurt School 150
Freikorps paramilitary units 58, 62, 71

French, Marilyn 231

French painting 4, 34, 188

Freud, Sigmund 1, 33, 196

Fried, Michael 18n3, 23, 46-7n47, 47n48, 47n 49,177

'Art and Objecthood' 36, 164

on Chevrier 46n45

Manet's Modernism, or the Face of

Painting in the 1860 s 164

'new regime of photography' 26

refutation of 'theatrical' in Morris's grey cubes 164

Why Photography Matters as Art as Never Before 4, 36-8

Friedan, Betty, The Feminist Mystique 151, 194

the frontier 51

the gaze $35,46 \mathrm{n} 37,121,171,175,18 \mathrm{o}, 183$, 196, 214-15

male $16-17,47 \mathrm{n} 54,173-4,175,196$, 215

psychoanalytical critique of $16-17$

theories of 202

see also perception; voyeurism

gender 12, 22-48, 150-3, 174-5, 161n 78 , 178,202

authorship and 151-2

Canadian landscape and 54-60

career and 151

colonialism and $82 \mathrm{n} 58$

construction of 214-15

'counter tradition' and 163-91

domesticity and 151

fields of conflict and 174-6

labour and 150-2

nature and $82 n_{5} 8$

representation and 134-53

social construction of 195

space and 143, 147, 148-9, 150, 151, 195

gentrification $17,242,247-8 \mathrm{n} 6 \mathrm{o}$

geography 5,150

see also feminist geography

George, Chief Dan 100 
George, Len 100-1

Gibb, William Phelan 'Harry' 68

Gilbert, Gerry 105

Gill, Don 236-7, 246n44

Glier, Michael 174

Godard, Jean-Luc 187

Goldberg, Michael 98

Golstein, Jack 43n1

Goodwin, Helen 97, 114

Gordon, Kim 174-5

Gore, Tom 217, 218, 219

Goya, Chantal 187

Graham, Dan 16, 24, 33, 46n37, 109, 123, $129,131-4,147,175$

Alteration to a Suburban House 33

Figurative 147, 148

Homes for America 116-17, 118, 130, 134

Graham, Rodney 2, 15, 89, 178, 19on22, 204, 233, 225n 35

refusal to be in Vancouver Art Gallery's exhibition 233

Stills from a Film in Progress 178

Greenberg, Clement 2, 8, 36, 47-8n56

Grip Limited 55

Group of Seven painters 13, 15, 42, 49-57, $60,62-3,67,95,156$

anti-modernist rhetoric and 57-8

avowal of heteronormativity by 59

Bucke and 8on22

Canadian identity and 53-4, 59, $81-2 n 49,81 n 31$

Carr and 69-72, 76

first exhibition at Art Gallery of Toronto 55

Housser and 56, 81n 40

sexual readings of 74

Gruft, Andrew 204

guerilla activism 132, 133

Guilbaut, Serge 40, 41, 47-8n56, 48n59, 246 n 32

Haacke, Hans 28, 39

Hammer Museum 49, 50, 79n3

Hammock, Virgil 152
Haraldsson, Arni 2, 15, 38, 47n53, 163 , 240

The Balsam and the Arbutus, Burnaby, $B C 238,239$

Harris, Lawren 15, 49, 50, 52-6, 63, 67, 69-70, 71, 74, 8on 22 , 8on 24

early canvasses of the Ward 56-7

The Idea of North exhibition 49, 79n3

influence on Carr 70

Mountain Farms 70

North Shore Lake Superior 49-50, 53, 60

Hayward Gallery 232

Hazleton, British Columbia 66

Heidegger, Martin 38, 47n49

Heizer, Michael 109

Henry, Karen 245n17

Henry, Mick (Michael) 102

Higgs, Matthew 142

Hill, Richard 222

historical painting 33, 50

Hitchcock, Alfred 29, 183

Holmes, Willard 29, 235

home 15-16, 148, 150

home-culture-concept 86-113, 150

homeland 15-16, 88, 136-7, 150, 192

Hornby Island 216, 220

Housser, Frederick 52, 53, 62, 8on22, 81n40

A Canadian Art Movement 51, 52, 55-6, 57

anti-immigrant sentiment of 57

Huelsenbeck, Richard 6, 8, 92-3, 220

humanism 203, 210, 212-13, 215-16

Hunter, Andrew 50, 79n3

Huyssen, Andreas 8-9, $20 n 37$

The Idea of North exhibition 49, 79n3

identity 53-4, 92, 195

see also specific identities

identity formation, avant-gardes and 10

identity politics 172,233

image

image production 2, 5

politics of 2,5

text and $180-1,211$ 
Image Bank 98, 101, 105

immigrants 13, 21n $50,42,51,54-5,57$, $60,62,81 n 38,96,154-6$

In Visible Colours: An International Women of Colour and Third World Women Film/ Video Festival and Symposium 231

inclusion 9-10, 231-3

see also feminist art practices; multiculturalism

Indigena: Contemporary Native Perspectives exhibition 232

indigenous others $12-13,86,156-7$ appropriations of $64-5,223$

in defeatured landscape 148-9 disappearance of 63,65 domestication of $61-3,65-6,8$ indigenous culture 64, 65, 217 settlers and 50, 86 sovereignty of $60-7$ see also First Nations

'inner-hegemonic' landscape 79, 90, 95, 109, 153-4, 192, 220

institutional discourse and power 128-9, 212, 230, 233

intentional communities 101-3

Interim exhibition 215

Intermedia 98, 105, 200

International Style architecture 34

Intertidal: Vancouver Art and Artists

$$
\text { 4-5 }
$$

Inuit artists 232

Irigaray, Luce 172

Itter, Carole 102, 105

Jackson, A.Y. 49, 55, 63, 69-70

Jacobs, Jane 156

Jencks, Charles 44n16

Jessup, Lynda 53, 81n31

Johnson, Frank 19on22 see also Ramirez, Frank

Johnson, Ray 125

Johnston, Frank 55

Jones, Amelia 173, 19on26

Judd, Donald 130-1, 171
Ka-shing, Li 238

Kaltenbach, Stephen 131

Kaprow, Alan 195

Kaufmann, Eric 8on12

Kelly, Mary 39, 19on17, 196, 215, 226n5o, 231

Interim exhibition 215

Post-Partum Document 171, 196, 215

Kiefer, Anselm 184

King, Ellen 97

Kirby, Bill 152

Kiyooka, Roy 97, 105, 213

Klein, Yves 195

Knights, Karen 245n17

Kosuth, Joseph 93, 125, 128-9, 131, 171

Kozloff, Max 173

Krasner, Lee 95

Krauss, Rosalind 27, 31, 43-4n1o, $44-5 \mathrm{n} 17,134-5,138,234$

Kristeva, Julia 178

Kruger, Barbara 28

Kuspit, Donald 4, 31-3, 35, 46n29

Kwakwaka wakw 63, 72

Kwon, Miwon 5, 39-40, 240

labour 55, 150-2

Lacan, Jacques 172, 196, 214-15

Lamoureux, Johanne 9, 75

land rights $12,16,155^{-6}, 222-3$ see also land use protests; territory Land, Spirit, Power exhibition 232 land use protests 154, 155, 222-3 landscape(s) 4-7, 12, 13, 53-4, 164, 211-12

changing 52

critical approach to 220

discourse and 239-40

double-coded as both material and representational space $238-40$

logic of elimination and 39-43

settler colonialism and 12, 41-2

spiritually pure $50-1$

see also Canadian landscape; landscape painting 
landscape painting 59-60, 62, 87, 90, 94-5 Canadian identity and 15

Expressionist 6, 13, 24, 42, 79, 109 ideological legacy of 88 indigenous sovereignty and $60-7$

Lang Rosenberg, Avis 201 'The Mother and the Whore (with apologies to French Filmmaker Jean Eustache)' 201

'Outfitter for Odd Jobs' 218-19

'Women Artists and Art History or Who in the World was Artemisia Gentileschi?' 201

'Women Artists of the Historic Past' 201

language $123,125,126,128,130,150,171$, 181,196

authority of $133-4$

of city-experience 133

deconstruction of 123, 125-6

identity and 195

as institutional power 128

limitations of 133

Laurence, Robin 226n5o

Lauter, Rolf $37-8$

Léaud, Jean-Pierre 187

Lee-Nova, Gary, 'Our Beautiful West Coast Thing' 11, 103-5, 126

Lefebvre, Henri 47-8n56, 131-2, 159n40

Levine, Sherrie 28, 43n1

Lewis, Glenn 101, 102

Lewitt, Sol 128

Lindberg, Ted 133

Linsley, Robert 6, 7, 56-8, 59, 94-5

Lippard, Lucy 78, 106, 120, 133, 151-3, $157-8 \mathrm{n} 15,161 \mathrm{n} 87,161 \mathrm{n} 88,196$, 198, 204

'liquid modernity' 9, 20n34

Lismer, Arthur 55, 56, 70

Lister, Ardele 200

lone tree symbolism 58-9, 62

Longo, Robert 43n1, 174

Look magazine 129-30, 143

looking act of 30, 181, 195-6

critical $32-3$ interrogating act of 195-6

technologies of $32-3$

see also the gaze; vision

Lowman, Emma Battell 61, 82n60

Lowndes, Joan 216-17

Lum, Ken 2-3, 15, 21n56, 87-9, 163, 164, $187,204,225 n 35,233$

Lunden, Duane 5, 106 Four Artists exhibition 123 Free Media Bulletin 6 The Locator 123

Lydon, John 30

Lynch, Kevin 127

MacDonald, J.E.H. 52, 55, 56, 63, 8on22

MacLeod, Danice $190 n 22$

MacMillan Bloedel 222-3

magazines 130, 142-3 see also specific magazines

Magiciens de la Terre exhibition 232

Magor, Liz 10, 17, 88-9, 202-3, 216-23

Bird Nest Kits 218

Breast Nest Pressers for the Perching Birds of Canada 218, 219

Cabin at Tetlayoko 220

Cheyenne Type 221-2, 221

Field Work 220-1, 222, 223

focus on human labour 219-20

Four Places exhibition 217, 218

Medicine Box 217

Magritte, René 169, 170

Mahovsky, Trevor 21n56, 148

Maimon, Vered 46-7n47, 47n48

male artists $150-3$ adoption of feminine subjectivities 193

avant-garde(s) and 234

feminist politics and 202

see also specific artists

male-female relationships 172, 181, 216

Malevich, Kazimir 104

Mallarmé, Stéphane 11, 184-6

Un coup de dés jamais nabolira le hazard (A throw of the dice will never abolish chance) 181 
Manet, Édouard 11, 167

A Bar in the Folies-Bergère 30, 35, 37

Manifest Destiny 51

manifestos 93-4, 128, 171

Maplewood Mudflats Community

$$
\text { 98-101, 104, } 105
$$

mapping 156

Marathon Realty Co. 154, 238

Maria, Walter de 109

Martin, Jean-Hubert 232

Martin, Steve 79n3

Marx, Karl, The German Ideology 91, 198-9

Marxist critiques 31, 87, 91, 202

masculinity $10,148,149,150,174-5$

mass culture $8-9,20 n 37,41$

mass media 40, 43n1, 67, 77-8, 166

Mastai, Judith 203, 231, 236, 246-7n45

the maternal 193, 202

Mayer, Baron de 185

Mays, John Bentley 45n23

McClintock, Anne 59

McLuhan, Marshall 97, 98, 114, 115, 126

Mead, Margaret 199

media 3, 123, 126, 128, 130, 185, 196, 199 see also mass media; specific media

The Medium is the Message 114

Metcalfe, Eric 101, 246n32

Meyer, John 127

Michelson, Annette 27

Military Voters Act 55

Millet, Kate 199

Minden, Robert 213

Minimalism 2, 130, 131, 133, 177, 212, 218

Minister Responsible for the Status of Women 194

Mitchell, Jeannine 224n15

modernism 2-4, 11, 20n34, 28, 36, 89, $167,176,186,188,213,232,244$ avant-garde critique within 16 Commonwealth 47-8n56, 49-85 crisis of 40-1

hegemonic discourses of 237

idealism of 240

male authorship and 40

women and 42-3, 192-227 modernity 9, 20n37, 34, 62, 88, 96, 131

Mohawk Nation 222

Moran, Jill 236-7, 243

Moray, Gerta 68

Morgan, Joey 89

Morris, Michael 98, 101, 246n32

Morris, Robert 130, 164, 171

motherhood 151

see also the maternal

movie theatres $135-6$

Mowat, Farley 148

Mudflats Living 99-101, 103

multiculturalism 231-3, 237

Mulvey, Laura 2on41, 47n54, 176, 231

lecture at Vancouver Art Gallery 231

'Visual Pleasure and Narrative

Cinema' 35, 183, 195-6

Museum of Modern Art

Information exhibition 153

'Primitivism' in 2oth Century Art: Affinity of the Tribal and the Modern exhibition 48n6o, 232

myth 16

cultural refusal of 92-3

'home culture concept' and 86-113

rejection of 92, 95

narrative $4,163,212$

narrative transfer 63, 64

National Film Board 99, 231

National Gallery of Canada 63-4, 153,

222, 232

National Museum(s) 66, 97

National school of painting 58

nationalism 28, 51, 92

Native land 222

see also land rights

'native' style 50

nature $10-12,21 n 48,52-4,71-2,87,216$, 219-20, 82n 58

in 'defeatured landscape' 148-9

femininity and $74-5$

representation of 59, 74-5, 109-10

Nauman, Bruce 125

Neil, Al 98 
neo-avant-garde photographic practices 4, 147-8

neo-Expressionism 3, 172

neoliberal capitalism 17, 19n15, 29, 241-2

NETCO 10, 97-8, 109, 114-23, 134, 150-3, 157-8n15, 157n1, 161n88, 193

Portfolio of Piles 10, 16, 115, 117-23, 119, $120,122,135,137,165,210,218$

Ruins 16, 115-16, 116, 117

Territorial Claim - Urination 148, 149, 156

N. E. Thing Co. 114-23, 157-8n15, 157n1 see also NETCO

new media technologies 90, 128-9

Newman, Barnett 95

Newman, Michael 167, 168-9

Nova Gallery 22, 22, 172, 190n22, 204

Nuu-chah-nulth Nation 63, 222

October 26, 27, 43-4n10

October Revolution 55

October Show 229

O’Doherty, Brian 131, 158-9n37

Oka, Quebec, crisis in 222

O'Keeffe, Georgia 84-5n107

Ono, Yoko 125

Onufrijchuk, Roman $245 \mathrm{n} 17$

the Other 37, 82-3n62

The Other Story: Afro-Asian Artists in

Post-War Britain exhibition 232

others 12

see also exogenous others; indigenous others

Owens, Craig 28, 43-4n1o

Pacific Vibrations exhibition 178

Pagonis, Ilya 106

painting $27-8,35,36$

see also specific schools of painting

Panofsky, Erwin 204

patriarchy 9, 171, 175, 195-6, 197, 215, 218, 236, 244

Pearson, Lester B. 194

pedestrian mobility 164
Pélenc, Arielle 33-4, 35, 46n37, 94, 243

Penner Bancroft, Marian 10, 17, 89, 97,

202-16

avant-gardes and 213, 215-16

Blind / Mat(t)er 212

For Dennis and Susan: Running Arms to a Civil War 205-7, 206, 210, 211

Mnemonicon (The Screen) 212, 213, 214-15

Shift 212

spiritland/Octopus Books 4th Avenue 211-12, 211

Spiritlands: t/HERE exhibition 212, 213

for Susan/ seasons after 207, 208-9, 210, 211

TRANSFIGURED WOOD Part 1, View from the Porch 207-9, 210

Vancouver photo-conceptualists and $202,203,210-14,215-16$

perception $127,141-2$

see also scanning; vision

performance art 195

Perry, Arthur 220

Perry, Sam 98

Pethick, Jerry 89

phenomenological experience 212, 218

photo-conceptualism 2, 4, 12, 202, 212

avant-gardes and 244

challenge to institutionalization of 'counter-tradition' of 235-7

'counter-tradition' of 235-7

women artists and 12, 215

see also Vancouver School of Photo-conceptualism

photo-conceptualists 87,90

'back to the land' lifestyle movement and $11-12$

feminism and 187-9, 202

theorization and representation of landscape by 12

women's movement and 202

see also Vancouver School of Photo-conceptualism 
The Photographer's Gallery 223-4n3

photography 3, 4, 26-30, 44n12

Cibachrome 115, 163

cinematographic photography 192, 210

critical role of $4,32-4,89$

of defeatured landscape 147-8

market for 172

neo-avant-garde 147-8

photographic transparencies 2

political potential of $28-9$

as readymade or indexical imprint 28 ,

$$
\text { 44-5n17 }
$$

as supplements to reality 135

Surrealism and 134-5, 138

photo-montage 28,130

Pictures exhibition 43n1, 45n18

Pinney, Marguerite 151-2

Piper, Adrian 171, 190n17, 234, 243

Place and Process exhibition 152

poetry $16,123,125,126,181,184-5$

see also specific poets and schools of poetry

Poetry: An Exhibition in Four Parts 125

Poisson, Renée 104, 106

political activism 154, 199-200

Pollock, Griselda 9, 10, 2on34, 192-3, 234, 243

Pollock, Jackson 95, 195

population economy, of settler colonialism 61-3

pornography 170

see also eroticism

portraiture, history of 34

post-colonialism 13, 41, 232

postmodernism 2, 4, 26, 44n16, 45n18

power 12, 13, 17, 175, 195, 202

consolidation of 216

defeatured landscape and 150

dynamics between view and sitter 35

institutional 230

mapping 237-42

'primitivism' 48n6o, 68, 95

Prince, Richard 28

private space $143,150,151$ productivism 28, 186

property ownership 154, 156

protest movements see land use protests

Proudhon, Pierre Joseph 8

psychoanalysis 196, 202, 214-15

psycho-geography 132, 133

public space 213

gender and 143, 150, 151

patriarchal experiences of 26

use and visualization of 143

Quebecois habitant 86

race and racism $12,37,51,54-60$

Ramirez, Frank 172-3, 176, 19on22

Ramírez, Juan Antonio 170

Ramsden, Anne 245n17

Rancière, Jacques 186

Razack, Sherene 12

readymades 30, 44-5n17, 163, 164, 165

Reaganism 27, 29

real estate $237-42$

realism 2, 8, 36

Red Flood 58

Reelfeelings 200

regional art production and history 5 , $12,87,88,109,230$

regionalism 3, 4-5, 40, 89, 156

regional landscape painting 87, 109

Reid, Terry 126

Reinhardt, Ad 6

representation

gender and 134-53, 202

see also women, representation of

politics of 223

Rimbaud, Arthur 92

Roehrich, Victor 103, 105

Roelstrate, Dieter 2, 4-5

romanticism 12, 30, 87, 106-10

Rombout, Luke 229

Rosenberg, Avis Lang 192

Rosler, Martha 28, 171, 190n17, 199

Rossellini, Roberto 183, 187 
Rothko, Mark 95

Roundtable on Feminism 231, $245 \mathrm{n} 17$

Roy, Marina 240-1

Royal Proclamation of 1763 61, 65

Ruscha, Ed 24, 109

Said, Edward 82-3n62

Saint-Simon, Henri 7-8

Salle, David 3

Sava, Sharla 163-4, 171-2

Savage, Harry 152

scanning 119, 126, 127, 128, 136, 156, 166

Schnabel, Julian 3

Schor, Gabriele 193

Schwarzkogler, Rudolf 173

scopophilia 175, 196

sculpture 99, 100, 165, 218

settler-artist, three categories of 90-1

settler colonialism 12-13, 15, 17, 59, 60-7,

69, 75-6, 82n6o, 84n83, 86-9, $155-6,222$

Carr and 71-2

cultural operations of 88,216

'indigenization' of settler population 61-3

land and 13, 222, 237-42

landscape and 41-2

population economy of 61-3

settler control $87,156-7$

settlers $12-13,50,51,76,86,156-7$

settler state $59,60,61-2,64-6$

Seventeen 143

sexism 193, 201

sexuality 10, 74, 137-8, 141-2, 148-9, 150, 192, 196

Shadboldt, Doris 11, 76-7, 85n111, 98, $102-3,105,229$

Shadboldt, Jack 74, 95, $111 \mathrm{n} 34$

Sharp, Dennis 247n 58

Shaw, Nancy 148, 151

Sherman, Cindy 28

Sieverding, Katharina 184

Silverman, Kaja 4, 30, 34-5, 36

Simmins, Richard 98, 229

Simmons, Richard 78
Simon Fraser University 2, 97, 98, 114, 215, 231

Simpson, Greg 126

Situationist International 16, 123, 131-3, 167

Smith, Andrea 12

Smith, Philip 43n1

Smith, Tony $164-5$

Smithson, Robert 6, 16, 24, 107, 123, 128, 130-1, 133, 134, 147, 171, 204

Glass Strata with Mulch and Soil 108

Glue Pour 106, 108, 165

'Incidents of Mirror Travel in the Yucatan' 106

Island of Broken Glass 106, 108-9

Map of Glass (Atlantis) 108

'The Monuments of Passaic' 107-8

'romantic extremism' of 106-10

Spiral Jetty 108

'A Tour of the Monuments of Passaic, New Jersey' 147

snapshots 126, 156, 165-7

Social Credit government 229-30

social critique $34,36,38-9,133,136-7$, 150

social justice $155,199-200$

'social practices' 96, 112n41

Soja, Edward 131

Solomon-Godeau, Abigail 44-5n17

Sontag, Susan 213-14

Soviet photofrescoes 28

space 164,172

gender and 143, 147, 148-9, 150, 195

spatially oriented concerns 5, 156

urban 131, 154, 155-6

see also urban landscapes

see also private space; public space

spectacle $4,37,132$

speculation $16,237-42$

Spicer, Jack 212

Spiritlands: t/HERE exhibition 212, 213

spirituality $11,12,15,21 \mathrm{n} 48,50-3,53,70$, 94-5

Sprong, Paul 100

squatting $5,7,104$ 
Stallabrass, Julian 19n15, 241-2

Statement of the Government of Canada on Indian Policy 155

Stephens, Godfrey 103

Strathcona 7, 154

subjectivity 184, 195, 196, 202

suburbia 115, 131, 134

Surrealism 10, 16, 30, 130-2, 134-5, 138, $141,147,160$ n68, 168-70,

$192-3,244$

symbolist poetry $181,184-5,188$.

tableau format 16, 36, 40, 168, 169, 176

Tallman, Warren 97

Tanabe, Takao 114

technology 32-3, 35-6, 39, 90, 114-15, $126,128-9,133-5,156$

see also specific technologies

telephones 115

Telex 114, 115, 157n4

terra nullius, colonial myth of 90

territory 17, 50-1, 216, 237-42

see also land rights

text, image and 180-1, 211

Thauberger, Althea 38, 47n53

theatricality $16-17,38,163,164-5,177$

THECO 97

Theosophy 49, 50, 52-3, 58, 62, 69, 71, $80 n 24$

Theweleit, Klaus 58-9

Thoreau, Henry David 52

Toche, Jean 6

Todd, Loretta 223

tokenism 234-5

totem poles $66,68,70$

tourism 66

transcendentalism 52, 186

transfer assimilation 63, 64

transfer narratives 63, 66, 69, 76, 87, 216

transfers $63,64,65$

see also specific types of transfers

Trasov, Vincent 98, 101, 102, 246n32

Tree, Penelope 30

Trocchi, Alexander 6

Trudeau, Pierre 102, 155
Tsilhqot'in Nation 62

Tsleil-Waututh First Nation 100-1

Turner, Frederick Jackson 51

Tzara, Tristan 8

University of British Columbia 2, 5-6, 91, 97-8, 105, 171, 177, 19on22, 203, 216, 228, 234, 246n32

Festival of the Contemporary Arts 114

Fine Arts Gallery 117, 119-20, 123, 125, 126

SUB Gallery 143

Women's Office Collective 198

women's studies courses at 199

urban development $17,131,154-5,237-42$

urban landscapes $6-7,115,123,135-7$,

$147-8,156,228$

'urban semiotic' 11-12, 16, 114, 123, 135, $137-8,141,150,211,213,237$

urban space $131,154,155-6$

see also urban landscapes

Van der Straet, Jan, Discovery of

America: Vespucci Landing in

America 59-60, 60, 82n 58

Van Eyk, Kristy 105

Vancouver, British Columbia 2, 5, 17, 42, 78,123

art community and production in 4-5, 89-90, 96-7, 228-30, 244

art market in $2-3$

avant-garde(s) in 4-5, 11-13, 40, 148-9, 192, 193-4

counter-tradition of critical art in 26 , 109-10

depiction of landscape of 4-7

displacement of working people from $242,247-8 \mathrm{n} 60$

feminist art practices in 196-202,

$230-1,244$

as 'gateway to the Orient' $98-9$

a-historicity and 16, 89-90

as integral node in global network of art making 4

land use protests in 154, 155-6 
landscape of $238-40$

landscape painting in $42-3$

modernism in 40-1

myth and 91-5

squatting in 5,7

transformation of 2, 17, 237-42

'urban-containment' policy in

$$
\text { 247-8n6o }
$$

urban development in 154-5, 237-42

women artists in 196-202, 230-1, 244

women-organized art events and collectives in the 1980s 230-1

see also Vancouver School of Photo-conceptualism

Vancouver Art and Artists 1931-1983 exhibition 89, 94, 204, 228-9

Vancouver Art Gallery 11, 17, 76, 77, 87, $108,178,197-8,233-4 \mathrm{~m}, 219$, $246 n 32$

change in directorship 228-9

'Emily Carr Symposium' 246-7n45

'An Evening Forum at the Vancouver Art Gallery' 235-7

lack of acquisitions from and exhibitions for women artists 234

lectures by Lang at 201

Modernist Controversies lecture series 234

panel discussions at $235-7,245 \mathrm{n} 17$

protests against 17, 229, 233

relocation of 228,230

rising national status of 98

Roundtable on Feminism 245n17

solo exhibitions of photo-

conceptualists at $233-4,241$, 246n3o, 246n32

women-organized art events and collectives in the 1980s 231

Women's Advisory Board 231

see also specific exhibitions

Vancouver artists 95, 240-1, 244

see also specific artists

The Vancouver Conference on Modernism 40-1, 47-8n56
Vancouver landscape 211-12

Vancouver Life 151-2

Vancouver School of Art 2, 97, 178, 203, 216

see also Emily Carr College of Art + Design

Vancouver School of Photoconceptualism 1-4, 11-17, 42-3, $61,67,87-8,123,163,189$, $225 n 35$

art market for $239-40$

avant-garde discourse and 233, 237

as brand 2, 203

capitalism and 241-2

challenges to $16-17,234,237-8,242$

discontinuities and continuities in $163-4$

as free-market-friendly 'countertradition' 242

gender and $8-11,17,147$

international acceptance of 239-40

marketing of 239-41

Marxist critique and 95-6

modernism and 244

Penner Bancroft and 202, 203, 210-14, $215-16$

reception of $240-1$

rejection of myth in all forms 95-6

self-defined counter tradition of 16

settler colonialism and 156

solo exhibitions at Vancouver Art

Gallery 233-4, 241

'urban semiotic' and 135

Vancouver Women's Bookstore 197, $224 \mathrm{n} 15$

Vancouver Women's Film and Video Festival 199-200

'Vancouverism' 17, 241

Vancouverism: Westcoast Architecture and City Building 241, 247n58

Varley, Frederick 55, 63

vehicles 16, 133-7, 156, 164, 165-6

Velazquez, Diego, Las Meninas 30

Veracini, Lorenzo 13, 15, 41-2, 61-3, 64, $82 n 60,86,89$ 
vérité 200

Verjee, Zainub 245n17

Vertical City 154, 244

video, feminist 197, 200

visibility $33-4$

vision $35-6,135,141,143,160$ n68, 214-15

visual culture 166, 195

Vogel, Susan 232

Von Meier, Kurt 117, 119

voyeurism 141, 169

\section{WACK!: Art and the Feminist Revolution} 193, 223-4n 3

Wall, Jeff $1-7,11,16,18 \mathrm{n} 3,21 \mathrm{n} 56,22-48$, $49,78,109,134,202,215$

absorption and $47 \mathrm{n} 49$

advertisements and 142

art-historical framework and 171-2, 176

avant-garde(s) and 30, 36, 40, 193-4

Carr and 67, 87, 94-5, 244

Cibachrome photography and 115, 163

Clark on $176-7$

comments on 'home' $87-8$

'counter-tradition' and 192, 193-4, 238

at Courtauld Art Institute 171

critical readings of $18 n_{3}, 30-5,35-9$

Debord and 132

defensive stance of $233,235-7$

in the Difference: On Representation

and Sexuality exhibition at the

New Museum, New York

20n 41

disavowal of regionalism 89

at 'An Evening Forum at the Vancouver Art Gallery' 235-7

feminism and 16, 40, 174-5, 187-9,

$$
\text { 192, 243-4 }
$$

Free Media Bulletin 6

Graham and 116

on institutional power $128-9$

interest in language and writing 171-2

Kelly and 226n5o

lecture at Witte de With Centre for Contemporary Art 87-8 on Lum's work 164

methodology of 93-4

Penner Bancroft and 203, 210

Phaidon monograph of $43 n_{5}$

in punk band $\mathrm{UJ}_{3} \mathrm{RK}_{5} 190 \mathrm{O}_{2} 2$

reception of 30-1, 45n23, 79, 94, 233

refusal to be in Vancouver Art

Gallery's exhibition 94, 233

rejection of 'home' and 'homeland' 15-16

self-positioning of $3,172,228$

on 'site of culture' 233

Situationist International and 132-3

'statement of position' at 'The Site of

Culture' panel discussion 233

'structure of intention' and 36

technology and 32-3, 35-6

transition to tableau format 16

at UBC 91, 171

'urban semiotic' and 114

use of photographic transparencies 2

visits Philadelphia Museum of Art

167-9

Wallace and 177-8, 184, 185, 186,

$$
187-8
$$

see also Wall, Jeff, exhibitions; Wall, Jeff, works

Wall, Jeff, exhibitions

Four Artists exhibition 123, 124, 127-9, 130, 133, 135-6

Poetry: An Exhibition in Four Parts 125

solo exhibitions 24-5, 29, 233-4, 241, 246n3o, 246n32

Wall, Jeff, works 10-11, 14-15, 29-30, 39, 45 n19

After 'Invisible Man' by Ralph Ellison, the Prologue 37, 38, 46n40

Berlin Dada and the Notion of Context 16, 76, 91-5, 171, 198-9

Clipped Branches, East Cordova St., Vancouver 37-8

Coastal Motifs 238

'Dan Graham's Kammerspiel' 33, $46 n 37$ 
The Destroyed Room 11, 15, 22-5, 22, $23,26,30-4,37,39-41,43 \mathrm{n} 5$, $168-77,188$, 190n 22

Double Self-Portrait 31, 174-5, 174

Faking Death 24-5, 29, 172-3, $190 \mathrm{n} 22$

The Giant 242-4, 242

Landscape Manual 6, 10, 24, 123, 124, $127-30,133,135-43,139-40$, $145,167,173,177,210-11$

Modernist Controversies lecture series 234

Movie Audience 3

Picture for Women 11, 15, 24-6, 25, $30-5,37,39-40,47 \mathrm{n} 54,136$, $171-7,180,188$

Shop Window, Paris 197730

'To the Spectator' 29-30, 31, 167

Stills from a Film in Progress 178

Young Workers 24, 30, 32

Wallace, Ian 2-5, 10-11, 31, 78, 89, 126-7, $175,203,213,225 \mathrm{n} 35,233$, $245 \mathrm{n} 17$

art-historical framework and 176 assessment of Carr 94-5 cinema and 136 on collages $170-1$ 'counter-tradition' and 192, 193-4, 238

Debord and 132

at 'An Evening Forum at the Vancouver Art Gallery' 235

feminist content and 16

feminist discourse and 186-9

Free Media Bulletin 6

gender conflict and 178

Graham and 116

on methodology 93-4

Penner Bancroft and 203, 210

on photo-conceptualism 202, 212

photographs of mid to late 1970 s 10-11

in punk band $\mathrm{UJ}_{3} \mathrm{RK}_{5}$ 19on22 refusal to be in Vancouver Art Gallery's exhibition 233 rejection of 'home' and 'homeland' 15-16

on scanning 127,128

self-conscious association with avant-garde(s) 3, 228

statement about his work 90

Wall and $177-8,184$

work described as literary 181

see also Wallace, Ian, exhibitions;

Wallace, Ian, works

Wallace, Ian, exhibitions

Four Artists exhibition 123, 129-30, 142-3

solo exhibition $233-4,246 \mathrm{n} 30$, $246 n 32$

Wallace, Ian, works $14-15$

L’Apres-Midi 186-7

An Attack on Literature I \& II 177-89, 182

Image/Text 11, 177-89, 185, 211

A Literature of Images 181

'Literature - Transparent and Opaque' $125-6,181$

Magazine Piece 123, 125, 126, 129-30, $142-3,210$

Masculin/Féminin 187

Pan Am Scan 143

'Photoconceptual Art in Vancouver' 2 review of Westkunst 3-4 Stills from a Film in Progress 178

Street Reflections 145, 146, 178

Study for Pan Am Scan 143, 144, 145

The Summer Script I and II 11, 177-89, $179,184,188$

Who Will I Become? 187, 188

Warhol, Andy 3, 166, 184

Watson, Scott 4-5, 6, 51, 59, 74, 75-6, 97, $111 n 34$

Weiner, Lawrence 152, 235

'West Coast Artists: Life Styles' 102-3, 105

West Coast Expressionist painting 79

Western Front 98, 101, 102

Westkunst: Contemporary Art Since 1939, Wallace's review of 3 
Wheeler, Dennis 5-6, 16, 78, 106, 114, 203, 204-7, 238

battle with leukaemia 205-7, 206 death of 207

review of Four Artists exhibition 123, 217

Whitehead, Alfred North 111n34

whiteness 12, 51

Whitlock, An 217

Whitman, Walt 52

Whitney Biennial 232

wilderness 62, 67, 71-2, 81n31, 123, 133, 148,216

see also nature

Williams, Carol 230-1, 236-7, 243, 246-7n 45, 246n 44

Wilson, Willie 101

Wisdom, David 19on22

Wolfe, Patrick 41, 82n6o

Wollen, Peter 20 41

women 10, 11, 143, 151, 170

bodies of 16-17

in defeatured landscape 148-9

as erotic repressed figure of modernism 42-3

exclusion of 8-10, 17

image of as muse and fetish 30

representation of 134-53,172, 184, 192, $196,199,242-4$ see also gender; women artists; women's movement

women artists $8-12,20 n 37,72,74,76-7$, $198,196-7,201,231-3,237,244$

see also specific artists

Women in Focus 198-9, 200-1, 231

'Women in Focus Audio-Visual Tape Library' 199

Women in Focus Gallery 200

Women's Inter-art Society (Women's Inter-art Co-op; WIS) 201-2

women's movement 9, 11, 20n37, 150-1, 170-2, 188-9, 194-202

The Wonder of It All 77

Wong, Paul 98, 232

Wood, William 203-4, 225n35, 233,

$$
246 n 30
$$

Xerox 114

Yaoyi, Shen 30

Yellow Peril: Reconsidered, a travelling exhibition 232

Zapf, Donna 245n17

Zaretsky, Eli 150

Zurich Dada 91-2 